\title{
Closed Loop Contol of ZCS Interleaved High Step Up Converter for Sustainable Energy Applications
}

\author{
Maria T Kuriyakose', Aswathy Rajan ${ }^{2}$ \\ ${ }^{1}$ PG Scholar, Department of Electrical and Electronics, Jyothi Engineering College, Cheruthuruthy, Thrissur, India \\ ${ }^{2}$ Assistant Professor, Department of Electrical and Electronics, Jyothi Engineering College, Cheruthuruthy, Thrissur, Kerala
}

\begin{abstract}
The Renewable energy is the best solution to satisfy the energy shortage without environmental problems. Photovoltaic energy is the most promising energy among the renewable energies. The main advantages includes long life and maintenance free and the main disadvantages are high installation cost and low conversion efficiency. The narrow turn off period of the conventional interleaved boost converter limits its application for high step-up applications. The interleaved boost converter with built in transformer voltage multiplier cells overcomes this drawback. This converter provides an additional control freedom to achieve extremely high voltage conversion ratio and minimize the ripple current. Additional advantages are switch voltage stress and conduction losses are also reduced. To study the performance of the high step up Interleaved DC-DC converter with closed loop control, simulations has been carried out in MATLAB2013 environment. Thus these current and voltage waveforms agreed with the operating principles and the steady-state analysis.
\end{abstract}

Keywords: boost conveter, interleaved converter,built in transformer voltage multiplier cell, regenerative diode, soft switching ( zcs).

\section{Introduction}

Nowadays, the renewable-energy grid-connected systems with photovoltaic (PV) and fuel cells call for high step- up and large-current $\mathrm{dc} / \mathrm{dc}$ topologies ,because the low voltage generated by the PV and fuel cells should be boosted to a relatively high dc bus voltage for the grid-connected generation systems. For example, in order to deliver the energy to a single-phase $220-\mathrm{V}$ utility grid, a $380-\mathrm{V}$ dc bus voltage is required with a full-bridge inverter. Unfortunately, the output voltage of most fuel cell stacks or the individual $\mathrm{PV}$ cells is lower than $40 \mathrm{~V}$ due to the safety and reliability issues in the household applications.

Large voltage conversion ratio with over ten times of voltage gain is necessary for the front-end $\mathrm{dc} / \mathrm{dc}$ converters. As a result, non-isolated high-step-up converters are desirable to reduce the system cost and improve the power density by removing the isolated voltage or current sensors and additional auxiliary power supply in the isolated conversion systems.

In this paper, the built-in transformer voltage multiplier cell is inserted into each phase of the conventional interleaved boost converter to provide additional control freedom for the voltage gain extension without extreme duty cycle. The voltage multiplier cell is only composed of the built-in transformer windings, diodes and small capacitors. And additional active switches are not required to simplify the circuit configuration.

Furthermore, the switch voltage stress and the diode peak current are also minimized due to the built-in transformer voltage multiplier cells to improve the conversion efficiency. Moreover, there is no reverse-recovery problem for the clamp diodes and the reverse recovery current for the regenerative and output diodes are controlled by the leakage inductance of the built-in transformer to reduce the relative losses. In addition, the switch turn-off voltage spikes are suppressed effectively by the ingenious and inherent passive clamp scheme and zero current switch (ZCS) turn-on is realized for the switches, which can enhance the power device reliability.

In a closed-loop control system, a sensor monitors the system output and feeds the data to a controller that adjusts the control to maintain the desired system output and hence remain unaffected to the external noise sources. A closed loop control has high reliability, easy implementation and output short circuit and overload protection.

With the decline in the production of fossil fuels, the sustainable energy sources such as the photovoltaic (PV),fuel cells and wind energy has been taken as the promising candidate for future energy supply. This energy sources has random energy fluctuations. To absorb the random energy fluctuation the sustainable energy sources require backup storage elements [1].The PV panel and back up battery cell has low output voltage. High step up boost converters are required to lift the low voltage to high one.

In industrial applications we require high voltage gain, so we depend on step-up converter. The conventional converters has many problems such as voltage stress, diode reverse recovery problems etc. The converter proposed in this paper can solve these problems.

Conventional Interleaved converter is an excellent candidate for the power factor correction applications. 


\section{International Journal of Science and Research (IJSR) \\ ISSN (Online): 2319-7064}

Index Copernicus Value (2013): 6.14 | Impact Factor (2014): 5.611

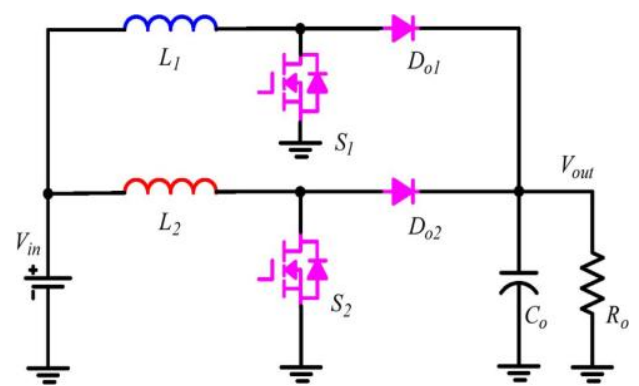

Figure 2.1: Conventional Interleaved boost Converter

For the conventional interleaved boost converter as shown in Fig. 2.1, the output voltage gain $M$ in continuous-current mode is simplified by

$$
M=\frac{1}{1-D}
$$

which is completely determined by the duty ratio. In highstep-up applications, the duty cycle becomes extremely large. Consequently, the turn-off period is very narrow, which is not practical for the industrial design. First, it is difficult to realize a duty ratio greater than 0.9 with typical PWM controller IC. Second, the narrow turn off period leads to a large current ripple. At last, the output diode reverserecovery losses are considerable. Furthermore, the voltage stresses of the switches and the output diodes are given by

$$
V_{d s}=V_{D o}=V_{\text {out }}
$$

The voltage stresses of the power devices are equal to the high output voltage. Therefore, the high switch voltage stress, the large current ripple, and the serious output diode reverse recovery problem are the main limitations for the conventional interleaved boost converters in high-step-up and high-output voltage conversion systems.

[2] uses an isolated dc-dc converter for high step up ratio applications. Overall efficiency is increased due to the resonance involving the transformer leakage inductance and the diode parasitic capacitances.ZVS turn ON of the main switch can be achieved due to the proper recirculation of the leakage inductance energy. In [3] to provide a large voltage conversion ratio a voltage doubler rectifier is introduced. Current fed type configuration reduces input current ripple.

To extend the converter voltage gain and to reduce the output diode voltage stress an advanced symmetrical voltage quadrupler rectifier is derived in [4].All the diodes in SVQR have same voltage and current stresses which simplifies the thermal design. The major considerations of Photovoltaic grid connected power system in the residential applications is discussed in [5].

[6] uses a novel configuration of the single phase three level PFC topology with the passive lossless snubber. To realize the soft switching of the main switches and freewheeling diodes two passive lossless snubber cells are added to the converter.[7] discusses design approach for server Power supplies for Networking Applications. The use of voltage multiplier technique in the classical non-isolated dc-dc converters to obtain high step up static gain is discussed in [8].The converter reduces the problems of EMI generation and diode reverse recovery problem.
[9] uses switched capacitor technique for high power high efficiency dc dc converter. The high pulse current at the switching transients which was the main drawback of the conventional switched capacitor techniques were overcome in the proposed converter.[10] discusses switched capacitor/switched inductor structures for getting transformerless Hybrid DC DC PWM converters. The main advantage of the new converters is their lower energy in the magnetic elements which leads to weight, size and cost saving for the inductors and thus for the power supply and less conduction losses which leads to better efficiency.

In [11] a Family of single switch PWM converters with high step up conversion ratio is discussed. The converter possesses higher voltage gain with small output voltage ripples. The main advantages of the converter are low voltage stress on the semiconductor devices, simple structure and control. The use of sepic integrated boost converter to distribute the voltage stress and to supplement the insufficient step up ratio is discussed in [12].

[14] discusses single phase improved active clamp coupled inductor based converter with extended voltage doubler cell. The secondary winding of the coupled inductor is inserted into the half wave voltage doubler cell to extend the voltage gain dramatically and decrease the switch voltage stress effectively. By introducing the extended voltage doubler cell the voltage stress of the switch and conduction losses is reduced greatly. Turns off voltage spikes on the main switch are suppressed and the leakage inductance energy is recycled.

In [15] a novel high step up DC DC converter with coupled inductor and voltage doubler circuit is proposed. Here the energy stored in the leakage inductor of the coupled inductor can be recycled.

[16] discusses High step up Boost converter integrated with a transformer assisted auxiliary circuit employing Quasi Resonant operation is discussed. The transformer leakage inductor and the balancing capacitor followed by the voltage doubler constitute a series resonant tank and thereby the sinusoidal current can considerably reduce the switch TURN OFF loss and the reverse recovery on the diode.

In [17] a highly efficient high step up converter for fuel cell power processing based on three state commutation cell is discussed. The main advantages of the converter are the size of the inductor is reduced and reduces the voltage stress across the active switches. But the drawback with the converter are 1) The frequency operation is low 2)The generation of PWM is complex because it should be implemented discretely due to the lack of dedicated integrated circuits.

[22] discusses General derivation law of non isolated converter derivation with direct energy transfer scheme has been proposed. The design considerations of an interleaved High step up interleaved High step up ZVT converter with built in transformer voltage doubler cell is discussed in [25].

This paper is organized as follows. Section II and III describes high gain sepic converter and its operation. 


\section{International Journal of Science and Research (IJSR) \\ ISSN (Online): 2319-7064}

Index Copernicus Value (2013): 6.14 | Impact Factor (2014): 5.611

MATLAB simulation along with results is explained in Section IV. Finally, the conclusion is stated in Section V.

\section{High Gain Interleaved Converter}

The paper introduces a high gain dc-dc boost converter for renewable energy systems. The basic configuration of proposed boost converter shown in figure 3 . The converter is derived from a traditional sepic converter. The high gain boost converter comprised of input inductor $\mathrm{L}_{\text {in }}$, coupled inductor T1, charge pump cell, buffer capacitor, regenerative snubber, output capacitor and load resistor $\mathrm{R}_{\mathrm{L}}$. The charge pump cell consists of $\mathrm{C}_{2}, \mathrm{D}_{1}$, and $\mathrm{D}_{\mathrm{o}}$. The regenerative snubber can provide zero-voltage and zero-current switching and recycles the captured leakage energy to the capacitor $\mathrm{C}_{1}$, which improves the efficiency of the converter.

In the proposed converter in order to achieve high gain and high step up, built-in transformer voltage multiplier cell is inserted into each phase of the conventional interleaved boost converter to provide additional control freedom for the voltage gain extension without extreme duty cycle. The voltage multiplier cell is only composed of the built-in transformer windings, diodes and small capacitors. And additional active switches are not required to simplify the circuit configuration.

Furthermore, the switch voltage stress and the diode peak current are also minimized due to the built-in transformer voltage multiplier cells to improve the conversion efficiency. Moreover, there is no reverse-recovery problem for the clamp diodes and the reverse recovery current for the regenerative and output diodes are controlled by the leakage inductance of the built-in transformer to reduce the relative losses. In addition, the switch turn-off voltage spikes are suppressed effectively by the ingenious and inherent passive clamp scheme and zero current switch (ZCS) turn-on is realized for the switches, which can enhance the power device reliability.

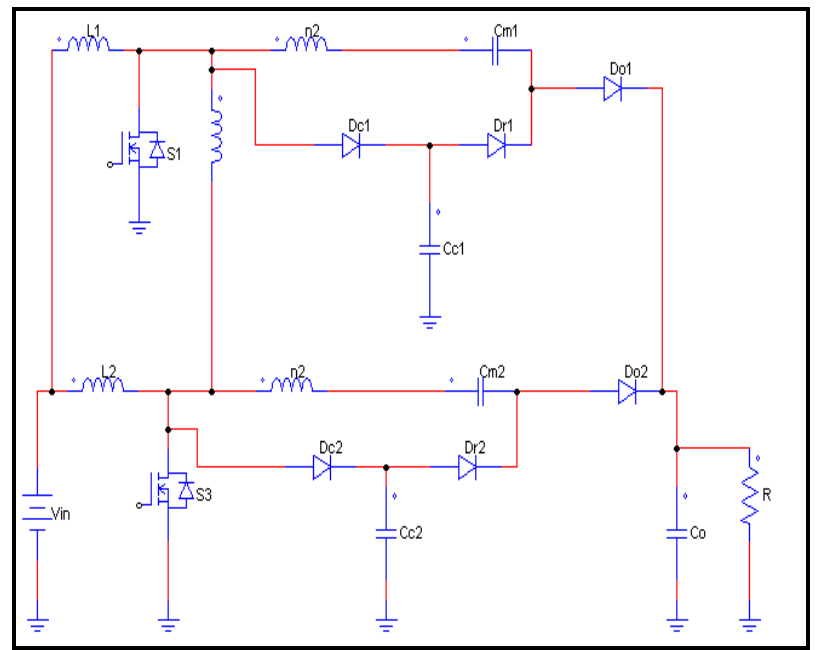

Figure 3: Circuit Diagram of the High Step Up Converter

\section{Operation of the Converter}

The proposed high step up interleaved converter with built in transformer voltage multiplier cell is shown in fig 4.1. $S_{1}$ and $S_{2}$ are the power MOSFETs, $L_{1}$ and $L_{2}$ are the input filter inductors, $D_{o 1}$ and $D_{o 2}$ are the output diodes, and $C_{o}$ is the output capacitor. There is a built-in transformer with three winding in the proposed converter. The primary winding is $n_{1}$ turns and the turns of the secondary and third windings are both $n_{2}$ turns. $L_{L k}$ is the leakage summation of built-in transformer reflected to the primary winding.

There are two built-in transformer voltage multiplier cells in the proposed converter. Each of the voltage multiplier cell is composed of the transformer winding with $n_{2}$ turns, clamp diode $D_{c 1(2)}$, regenerative diode $D_{r 1(2)}$, clamp capacitor $C_{c 1(2) \text {, }}$ multiplier capacitor $C_{m 1(2) .} V_{\text {in }}$ and $V_{\text {out }}$ are the input and output voltages, respectively. $N$ is defined as the turns ratio $n_{2} / n_{1}$ of the built-in transformer. There are 12 main operational stages in one switching period.

First switches $S_{1}$ and $S_{2}$ are both in the turn-on state. Clamp diodes $D_{c 1}$ and $D_{c 2}$, regenerative diodes $D_{r 1}$ and $D_{r 2}$, and output diodes $D_{o 1}$ and $D_{o 2}$ are all reverse-biased. Both the two input inductors $L_{1}$ and $L_{2}$ are charged by the input voltage $V_{\text {in }}$ respectively. Now switch $S_{2}$ turns off, its parasitic capacitor $C_{s 2}$ is charged by the current of the input inductor $L_{2}$ in an approximately linear way.

The drain-source voltage $v_{d s 2}$ is charged and increased to make clamp diode $D_{c 2}$ forward-biased. Then $D_{c 2}$ begins to conduct and clamp capacitor $C_{l}$ is charged by the current of the input inductor $L_{2}$ linearly. Switch $S_{2}$ turns off and its drain-source voltage $v_{d s 2}$ is clamped by capacitor $C_{c 2}$. The voltage of output diode $D_{o 2}$ decreases to zero and it begins to turn on. As the current through $D_{o 2}$ increases, the current through clamp capacitor $C_{c 2}$ decreases. The multiplier capacitors $C_{m 1}, C_{m 2}$, the second and third windings of the built-in transformer operate as voltage sources. This is the inherent reason why the proposed converter can greatly extend the voltage gain. Meanwhile, regenerative diode $D_{r 1}$ begins to conduct. The energy stored in clamp capacitor $C_{c 1}$ starts to transfer to multiplier capacitor $C_{m 1}$ through regenerative diode $D_{r 1}$, second winding of built-in transformer and switch $S_{1}$. The current through $C_{c 1}$ and $C_{m 1}$ is controlled by the leakage inductance $L_{L k}$. Now, the current through clamp capacitor $C_{c 2}$ decreases to zero and clamp diode $D_{c 2}$ turns off naturally. As a result, there is no reverse-recovery problem for the clamp diodes. The energy stored in the multiplier capacitor $C_{m 2}$ continues to transfer to the load .Due to the leakage inductance $L_{L k}, S_{2}$ turns on with zero current switch (ZCS) soft switching condition. The current falling rate through output diode $D_{o 2}$ is controlled by leakage inductance $L_{L k}$, which alleviates the output diode reverse-recovery problem. This stage ends when output diode $D_{o 2}$ turns off.

\section{Simulation Results}

The simulation of ZCS interleaved high step up converter with built in transformer voltage multiplier cell has been carried out. An input voltage of $40 \mathrm{~V}$ and switching frequency of $100 \mathrm{kHz}$ is chosen and an output of $380 \mathrm{~V}$ is obtained. The duty ratio of the switches are equal and the corresponding parameters are listed in Table I. Fig 4 shows the simulation waveforms of the converter (a) the input voltage, output voltage and current waveforms. (b) Voltage and current across the switch. Zero current switching is 


\section{International Journal of Science and Research (IJSR) \\ ISSN (Online): 2319-7064}

Index Copernicus Value (2013): 6.14 | Impact Factor (2014): 5.611

achieved. (c) Input inductor current, primary and secondary current of the coupled inductor. (d) Output diode voltage and current waveform. Fig 5, fig 6 shows the waveform of line and load regulation respectively.

Table 1: Simulation Parameters

\begin{tabular}{|c|c|}
\hline Parameters & value \\
\hline Input voltage $\mathrm{V}_{\mathrm{s}}$ & $40 \mathrm{~V}$ \\
\hline Output voltage $\mathrm{V}_{\mathrm{o}}$ & $380 \mathrm{~V}$ \\
\hline Output power $\mathrm{P}_{\mathrm{o}}$ & $1000 \mathrm{~W}$ \\
\hline Switching frequency $\mathrm{f}_{\mathrm{s}}$ & $100 \mathrm{kHz}$ \\
\hline Turns ratio $\mathrm{N}_{1}: \mathrm{N}_{2}$ & $14: 14$ \\
\hline Input Inductor & $50 \mu \mathrm{H}$ \\
\hline Capacitance of $\mathrm{C}_{\mathrm{m} 1}\left(\mathrm{C}_{\mathrm{m} 2}\right)$ & $4.7 \mu \mathrm{F}$ \\
\hline Capacitance of $\mathrm{C}_{\mathrm{c} 1}\left(\mathrm{C}_{\mathrm{c} 2}\right)$ & $4.7 \mu \mathrm{F}$ \\
\hline Capacitance of $\mathrm{C}_{0}$ & $470 \mu \mathrm{F}$ \\
\hline Output Resistor & $144.4 \Omega$ \\
\hline
\end{tabular}

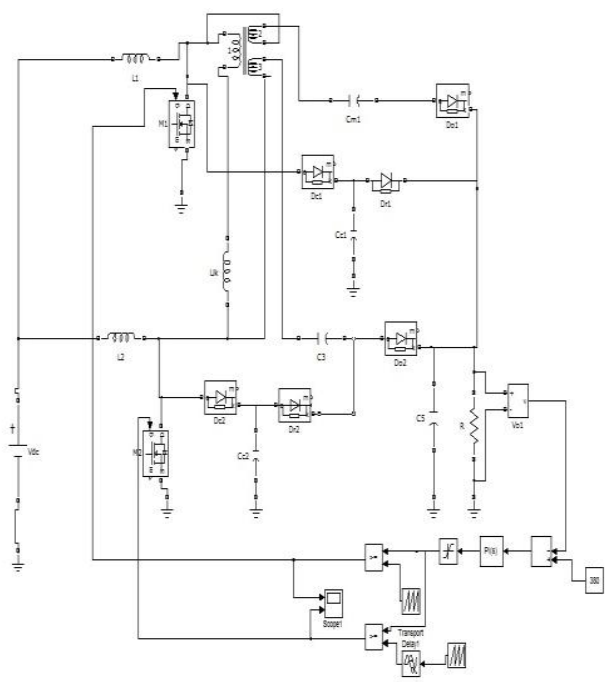

Figure 4: Simulink model of the converter
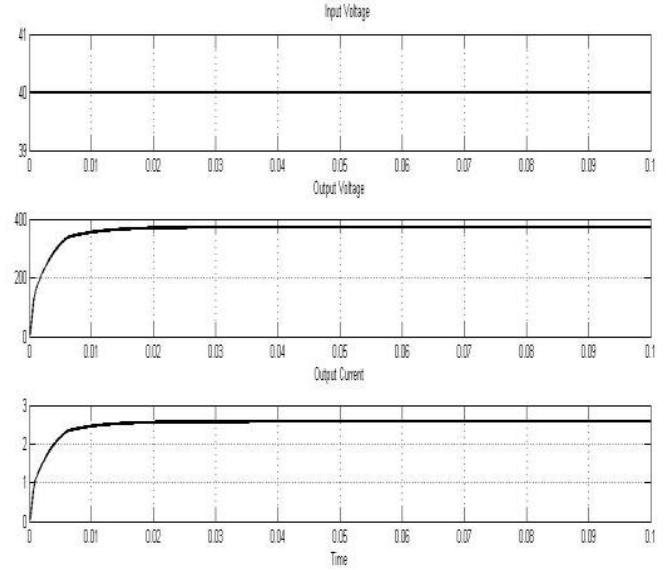

Figure a) Input voltage, Output Voltage and Output Current

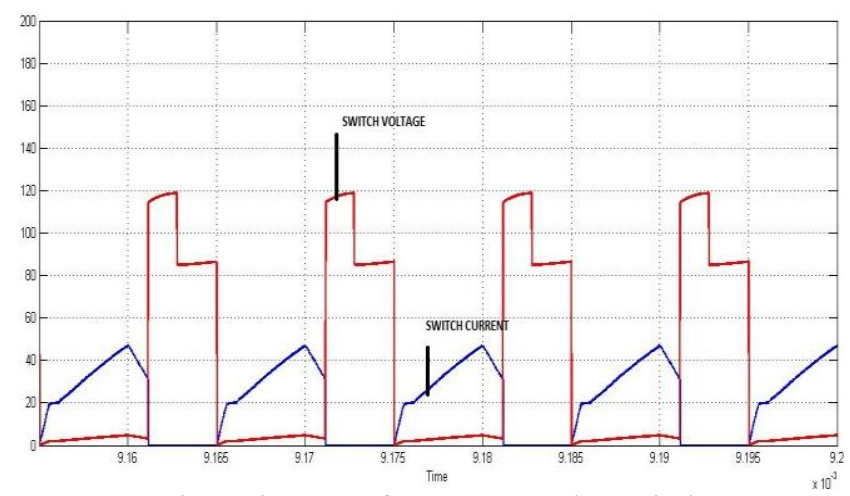

Figure b) Waveforms across the switch
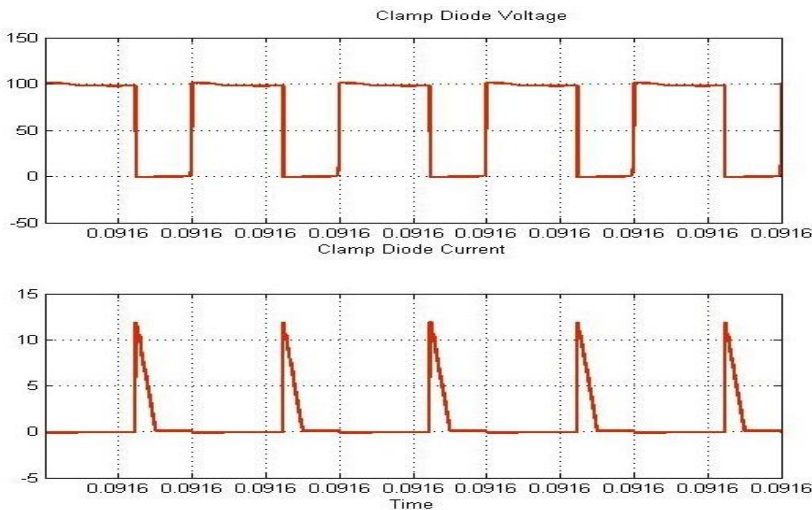

Figure c) Waveforms across clamp Diode

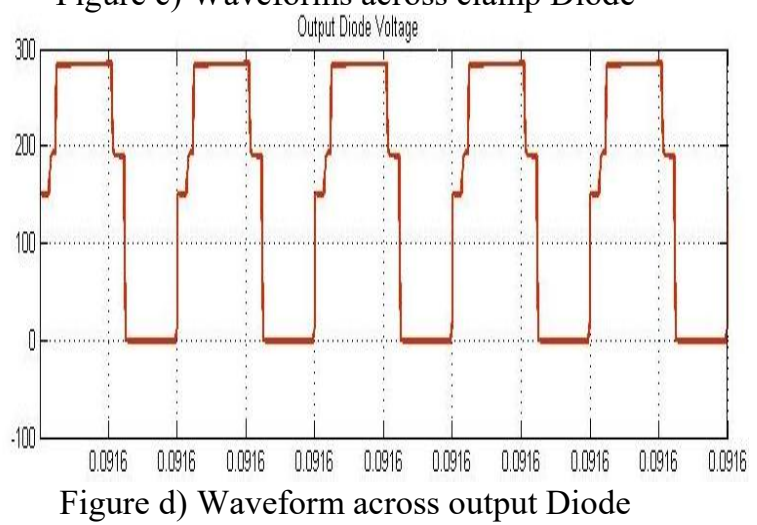

Due to the leakage inductance of the built in transformer ZCS Turn on is realised for the switches. From the waveform it is clear that clamp diode turns off naturally.Consequently there is no reverse recovery problem for the clamp diodes. The current falling rate of the output diode is controlled by the leakage inductance of the built in transformer,which alleviates the diode reverse recovery problem.From the waveform it is clear that voltage stress of output diode voltage is less than the output voltage.

Fig 4: simulation results: (a) input and output voltage, output current, (b) Waveforms across the switch (c) Waveforms across clamp diode voltage (d) output diode voltage 


\section{International Journal of Science and Research (IJSR) ISSN (Online): 2319-7064}

Index Copernicus Value (2013): 6.14 | Impact Factor (2014): 5.611

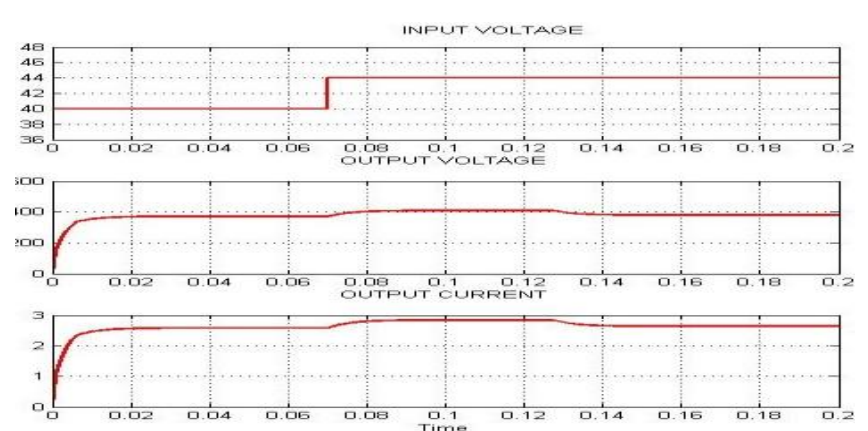

Figure 5: Line regulation of the converter (input voltage $=44 \mathrm{~V}$ )
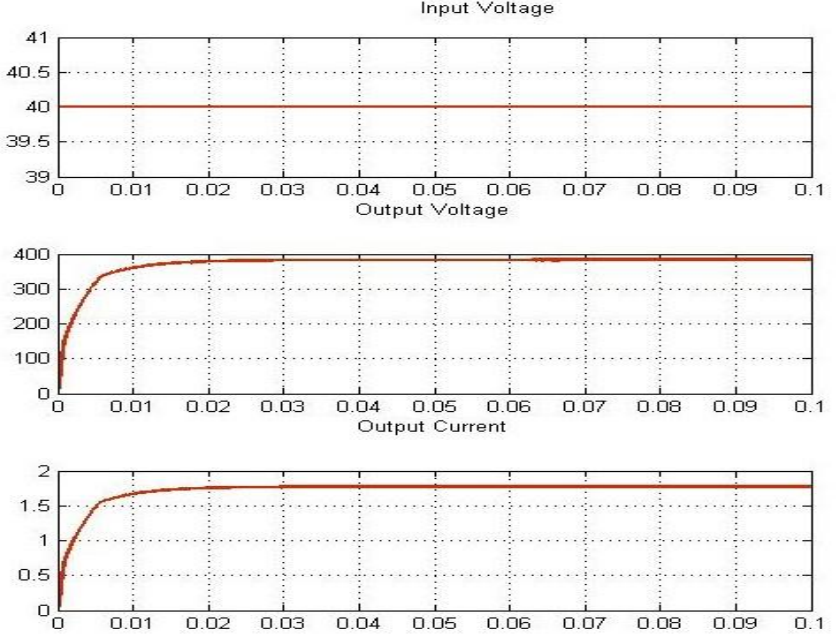

Figure 6: load regulation of the converter obtained at half load

\section{Conclusion}

The paper introduces closed loop control of high step up interleaved converter with built in transformer voltage multiplier cell for secondary grid connected applications. An additional control freedom is provided by the built in transformer voltage multiplier cell to achieve extremely high voltage conversion ratio and to minimize the current ripple. The switch voltage stress is reduced $(26.3 \%)$ to make the low voltage rated power device and the conduction losses are reduced.ZCS is achieved for the switches and the diode reverse recovery problem is alleviated to improve the conversion efficiency. The validity is tested by using the MATLAB software and obtained the required output.

\section{References}

[1] Y.Gu,W. Li,Y. Zhao, B.Yang, C. Li, and X. He, "Transformerless inverter with virtual DC bus concept for cost-effective grid-connected PV power systems," IEEE Trans. Power Electron., vol. 28, no. 2, pp. 793805, Feb. 2013.

[2] G. Spiazzi, P. Mattavelli, and A. Costabeber, "High step-up ratio flyback converter with active clamp and voltage multiplier," IEEE Trans. Power Electron., vol. 26, no. 11, pp. 3205-3214, Nov. 2011.

[3] W. Li, L. Fan, Y. Zhao, X. He, D. Xu, and B.Wu, "High step-up and high efficiency fuel cell power generation system with active clamp flybackforward converter," IEEE Trans. Ind. Electron., vol. 59, no. 1, pp. 599-610,
[4] Y. Zhao, X. Xiang, W. Li, X. He, and C. Xia, "Advanced symmetrical voltage quadrupler rectifiers for high step-up and high output-voltage converters," IEEE Trans. Power Electron., vol. 28, no. 4, pp. 1622$1631,2013$.

[5] W. Li and X. He, "Review of non-isolated high step-up DC/DC converters in photovoltaic grid-connected applications," IEEE Trans. Ind. Electron., vol. 58, no. 4, pp. 1239-1250, 2011.

[6] H.Wu and X. He, "Single phase three-level power factor correction circuit with passive lossless snubber," IEEE Trans. Power Electron., vol. 17, no. 6, pp. 946-953, Nov. 2002.

[7] L. huber and M. M. Jovanovic, "A design approach for server power supplies for networking," in Proc. IEEE INTELEC'00, 2000, pp. 1163-1169.

[8] M. Prudente, L. L. Pfitscher, G. Emmendoerfer, E. F. Romaneli, and R. Gules, "Voltage multiplier cells applied to non-isolated DC-DC converters," IEEE Trans. Power Electron., vol. 23, no. 2, pp. 871-887, Mar. 2008.

[9] F. Zhang, L. Du, F. Z. Peng, and Z. Qian, "A new design method for high-power high-efficiency switchedcapacitorDC-DC converters," IEEE Trans. Power Electron., vol. 23, no. 2, pp. 832-840, Mar. 2008.

[10]B. Axelrod, Y. Berkovich, and A. Ioinovici, "Switchedcapacitor/ switched-inductor structures for getting transformerless hybrid DC-DC PWM converters," IEEE Trans. Circuits Syst. I, Reg. Papers, vol. 55, no. 2, pp. 687-696, Mar. 2008.

[11]E. H. Ismail, M. A. Al-Saffar, A. J. Sabzali, and A. A. Fardoun, "A family of single-switch PWM converters with high step-up conversion ratio," IEEE Trans. Circuits Syst. I, Reg. Papers, vol. 55, no. 4, pp. 11591171, May 2008.

[12] K. B. Park, G. W.Moon, andM. J. Youn, "Nonisolated high step-up boost converter integrated with sepic converter," IEEE Trans. Power Electron., vol. 25, no. 9 , pp. 2266-2275, Sep. 2010.

[13]K. C. Tseng and T. J. Liang, "Novel high-efficiency step-up converter," in Proc. IEE-Elect. Power Appl., vol. 151, no. 2, Mar. 2004, pp. 182-190.

[14]Y. Zhao,W. Li, and X. He, "Single-phase improved active clamp coupledinductor- based converter with extended voltage doubler cell," IEEE Trans. Power Electron., vol. 27, no. 6, pp. 2869-2878, Jun. 2012.

[15] L. S. Yang, T. J. Liang, H. C. Lee, and J. F. Chen, "Novel high step-up DC-DC converter with coupledinductor and voltage-doubler circuits," IEEE Trans. Ind. Electron., vol. 58, no. 9, pp. 4196-4206, Sep. 2011.

[16] K. B. Park, G. W. Moon, and M. J. Youn, "High step-up boost converter integrated with a transformer-assisted auxiliary circuit employing quasi-resonant operation," IEEE Trans. Power Electron., vol. 27, no. 4, pp. 19741984, Apr. 2012.

[17] S. V. Araujo, R. P. Torrico-Bascope, and J. V. TorricoBascope, "Highly efficient high step-up converter for fuel-cell power processing based on three-state commutation cell," IEEE Trans. Ind. Electron., vol. 57, no. 6, pp. 1987-1997, Jun. 2010.

[18] G. A. L. Henn, R. N. A. Silva, P. P. Praca, L. H. S. Barreto, and D. S. Oliveira, "Interleaved-boost 


\section{International Journal of Science and Research (IJSR) \\ ISSN (Online): 2319-7064}

Index Copernicus Value (2013): 6.14 | Impact Factor (2014): 5.611

converter with high voltage gain," IEEE Trans. Power Electron., vol. 25, no. 11, pp. 2753-2761, Jan. 2010.

[19] W. Li and X. He, "A family of interleaved DC/DC converters deduced from a basic cell with windingcross-coupled inductors (WCCIs) for high step-up or step-down conversions," IEEE Trans. Power Electron., vol. 22, no. 4, pp. 1499-1507, Jul. 2008.

[20] W. Li, Y. Zhao, J. Wu, and X. He, "Interleaved high step-up converter with winding-cross-coupled inductors and voltage multiplier cells," IEEE Trans. Power Electron., vol. 27, no. 1, pp. 133-143, Jan. 2012.

[21] K. B. Park, G. W. Moon, and M. J. Youn, "Nonisolated high step-up stacked converter based on boostintegrated isolated converter," IEEE Trans. Power Electron., vol. 26, no. 2, pp. 577-587, Feb. 2011.

[22] W. Li, W. Li, X. He, D. Xu, and B. Wu, "General derivation law of nonisolated high step-up interleaved converters with built-in transformer," IEEE Trans. Ind. Electron., vol. 59, no. 3, pp. 1650-1661, Mar. 2012.

[23]H.-L. Do, “Asoft-switching dc/dc converter with high voltage gain," IEEE Trans. Power Electron., vol. 25, no. 5, pp. 1193-1200, May. 2010.

[24] Y. Deng, Q. Rong, W. Li, Y. Zhao, J. Shi, and X. He, "Single switch high step-up converters with built-in transformer voltage multiplier cell," IEEE Trans. Power Electron., vol. 27, no. 8, pp. 3557-3567, Aug. 2012.

[25] W. Li, X. Xiang, C. Li, W. Li, and X. He, "Interleaved high step-up ZVT converter with built-in transformer voltage doubler cell for distributed PV generation system," IEEE Trans. Power Electron., vol. 28, no. 1, pp. 300-313, Jan. 2013. 